\title{
An examination of socioeconomic equity in health experiences in six Latin American and Caribbean countries
}

\author{
Jessica Greene ${ }^{1}$ and Frederico Guanais ${ }^{2}$
}

Suggested citation

Greene J, Guanais F. An examination of socioeconomic equity in health experiences in six Latin American and Caribbean countries. Rev Panam Salud Publica. 2018;42:e127. https:/ / doi.org/10.26633/ RPSP.2018.127

\begin{abstract}
Objective. Most Latin American and Caribbean (LAC) countries are working toward the provision of universal health coverage, and ensuring equity is a priority for those nations. The goal of this study was to examine the extent to which adults' socioeconomic status was related to health care experience in six LAC countries.

Methods. This cross-sectional study examined the relationship between educational attainment and seven health experience outcomes in three areas: assessment of the health system, access to care, and experience with general practitioner. For this work, we used data from an Inter-American Development Bank survey of adults in Brazil, Colombia, El Salvador, Jamaica, Mexico, and Panama that was conducted in 2012-2014.

Results. Brazil and Jamaica, the two countries with unified public coverage, stood out for having substantially greater inequality, according to the results of bivariate analyses, with more-educated respondents reporting better health care experiences for five of the seven outcomes. For Jamaica, educational differences largely remained in multivariate analyses: college graduates were less likely (odds ratio $(O R)=0.37$ ) than those with primary education to report their health system needs major reform and were more likely $(O R=2.57)$ to have a regular doctor. In Brazil, educational differences were mostly eliminated in multivariate models, though people with private insurance consistently reported better outcomes than those with public coverage. Colombia, in contrast, exhibited the least inequality despite having the highest income inequality of the six countries.

Conclusions. Future research is needed to understand the policies and strategies that have resulted in Colombia achieving high levels of equity in patient health care experience, and Jamaica and Brazil demonstrating high levels of inequality.
\end{abstract}

Keywords Health equity; coverage equity; equity in access to health services; Latin America; West Indies.

Over the last three decades, with the rise of democracy in Latin America and

\footnotetext{
Marxe School of Public and International Affairs, Baruch College, City University of New York, New York City, New York, United States of America. Send correspondence to Jessica Greene, at jessica.greene@baruch.cuny.edu

Inter-American Development Bank, Lima, Peru.
}

the Caribbean (LAC) and international calls for universal health coverage, more than half of the 33 LAC countries have established the right to health in their constitutions $(1,2)$. Most LAC countries are in the process of expanding health coverage to reach the goal of universal coverage, and, as a result, health coverage has expanded considerably in the LAC region (3-7). Since the early 2000s, according to an estimate by the Pan American Health Organization (PAHO), 46 million people have gained health coverage in 10 LAC countries (8). Another analysis found that across 16 Latin American countries, the coverage 
rate increased from $54 \%$ in 2002 to $66 \%$ in 2011 (9).

The World Health Organization defines universal health coverage as providing "all people with access to needed health services of sufficient quality to be effective," and ensuring that use of health services does not result in financial hardship (10). Given the focus on providing services to "all people," equity is an integral component of universal health coverage (11). However, working toward universal health coverage has not always resulted in equitable access to quality health care. In fact, due to trickledown patterns of access and barriers faced by more vulnerable populations, universal health coverage has increased inequality in some countries (12-14). The extent to which the path to universal health coverage impacts health care equity is particularly relevant in Latin America and the Caribbean, since it is the region of the world with the greatest income inequality (15).

The evolution of health coverage in LAC has also raised concerns about health coverage equity $(1,2,16)$. In most LAC countries, health coverage was initially developed in connection with formal-sector employment, through social security systems created in the mid-twentieth century, and financed through payroll contributions. Since many people in the LAC region do not work in the formal sector, separate noncontributory systems financed by general taxation were subsequently developed to provide health care to those working in the informal sector and for the poor, and in most countries these services are provided by the ministry of health $(17,18)$. As a result, most LAC countries have historically had two separate public sector systems, with the contributory (or social security) system being better financed and offering more comprehensive benefits than the noncontributory system, which serves a more vulnerable population (16). Private insurance is also available in most LAC countries, typically as supplementary coverage, and it disproportionately covers the wealthy, further segmenting the population by socioeconomic status (19).

Segmented public health coverage is considered a key driver of socioeconomic inequities in health care $(3,16,17,20)$, and one article recently described it as "ethically and politically unacceptable" (2). LAC countries have sought to address the problems of segmentation in different ways. A few, including Brazil, Costa Rica, and Cuba, unified their public systems decades ago, while most LAC countries have relatively recently sought to equalize funding and benefits across the two public systems $(6,16,21)$. While there has been progress, $\mathrm{PAHO}$ has recently identified addressing inequality as a priority for the Region of the Americas $(17,22,23)$. PAHO's Sustainable Health Agenda for the Americas 20182030, which was endorsed by the PAHO Member States in 2017, states that "in the coming years, our focus must be on ensuring equity in health, so that all people can benefit from the major push for universal access to health and universal health coverage" (4).

This study examines socioeconomic equity in people's health care experiences in 6 LAC countries: Brazil, Colombia, El Salvador, Jamaica, Mexico, and Panama. In each of the countries, people have a constitutional right to access at least one type of health care coverage, though people's access to care is not necessarily assured (20). A prior study found substantial variation in patientreported outcomes in these same 6 countries (24). For example, the percent of people who believed that their health care system needed major reform ranged from a low of $27 \%$ in Mexico to a high of $55 \%$ in Brazil. While the prior study did not explore equity in health care experiences, a 2007 survey of people in 17 Latin American countries found substantial differences in income-based gaps in access to care among the nations. Highand low-income people in both Costa Rica and Panama reported almost the same level of problems (3 percentage point difference). In contrast, low-income people in Bolivia and Peru, respectively, reported 27 and 28 percentage points greater access problems than did high-income people (25). This range in equity is consistent with research on equity in health care utilization across the LAC region (21-23).

In this study we specifically examine the extent to which people's educational attainment is related to their assessment of the health care system, access to care, and experience with general practitioners. We further examine the extent to which the type of health coverage is related to health experiences, and whether controlling for type of health coverage reduces educational inequality.

\section{METHODS}

\section{Study design and population}

This cross-sectional study uses the Inter-American Development Bank's (IADB) Survey on Access, Experience, and Coordination of Primary Health Care in Latin America and the Caribbean, which was conducted in six LAC countries between late 2012 and early 2014 . The survey was adapted and translated from the Commonwealth Fund International Health Policy Survey, which has examined perceptions of access and barriers to care, and has assessed health care systems overall in as many as 11 high-income countries, depending on the year of the survey (26, 27). The IADB survey was conducted in South America (Brazil and Colombia), Central America (El Salvador and Panama), the Caribbean (Jamaica), and North America (Mexico).

The survey, which was translated into Spanish and Portuguese for use in Latin American countries, was conducted by Harris Interactive by random digit dial of both landline and mobile phones (5). Approximately 1500 adults were surveyed in each country, with response rates ranging from $29 \%$ in Colombia to $44 \%$ in El Salvador. Weights were developed so that respondents' demographic characteristics (age, gender, education, and geography) were similar to national census data in each country. The survey data is available on the IADB's website (https:/ / publications.iadb.org/handle/11319/9095).

\section{Variables}

The key independent variable in this study was educational attainment level, which was categorized into three levels: primary school completion, high school or vocational school degree, and college degree or higher. We focused on education because it was collected consistently in the six countries, whereas income was only collected in Jamaica. We conducted supplementary analysis with data from Jamaica and found that the relationships we observed between education and the dependent variables were very similar to what we observed using income.

We also examined whether type of health coverage was related to health experiences. We categorized respondents as having private, contributory, or noncontributory health coverage. If respondents 
had more than one type of coverage, we categorized them as having the more expensive coverage.

We examined equity across seven dependent variables, which fell into three categories: assessment of health care system, access to care, and experience with general practitioner. For the assessment of the country's health care system, respondents were asked how they would characterize their country's health care system, and we examined the percentage selecting the least positive of three options: "Our health care system has so much wrong with it that we need to completely rebuild it" (26). Respondents were also asked how confident they would be to "receive the most effective treatment, including drugs and diagnostic tests," if they were to become seriously ill. We examined the percentage that reported they were "very" or "somewhat" confident.

For access to care, respondents were asked if they had a doctor whom they usually see for medical care, and whether they had had a medical problem in the preceding 12 months but had not visited a doctor because of cost. We examined those reporting having a usual doctor and those who skipped a doctor visit because of cost.

There were three questions related to patients' experience with their general practitioner, which were answered by the subset of respondents who reported having a doctor or clinic where they regularly received care. Respondents rated the medical care they had received in the previous 12 months from their regular doctor or clinic. We examined the percentage who responded that it was "good," "very good," or "excellent." Respondents also reported the frequency with which their doctor or medical staff explained things "in a way that is easy to understand," as well as the frequency with which their doctor or medical staff gave them "an opportunity to ask questions about recommended treatment." For these last two items, we examined the percentage reporting "always" or "often."

\section{Analytic approach}

After conducting basic descriptive statistics, we examined bivariate relationships between education level and each of the dependent variables for each country using the chi-square test.
Since we anticipated that education level would be highly related to the type of health coverage, we examined this relationship in each country. We then developed multivariate logistic regression models examining the independent relationship of education level and type of health coverage to each outcome, controlling for gender, age, and selfreported health status, in each of the six countries. In all analyses, observations were weighted and standard errors were adjusted for the sample design. A $p$ value less than .05 was considered statistically significant.

\section{RESULTS}

Respondents from Colombia, Jamaica, and Mexico had the highest levels of education overall; approximately $20 \%$ had college degrees, slightly over half had high school degrees, and a quarter completed primary education (Table 1). El Salvadoran and Panamanian respondents had slightly higher rates of college degrees, but substantially more respondents with only primary education (43\% in each country). Brazilian respondents' education levels were the lowest, with $64 \%$ having just completed primary education.

In Brazil and Jamaica, there is one public coverage system, while in the other four countries there are segmented public systems (Table 1). In those four countries, the contributory systems cover the largest percentage of the population (from $47 \%$ in El Salvador to $68 \%$ in Colombia), while the noncontributory system covers a small percentage (from $15 \%$ in Panama to $43 \%$ in El Salvador). Private coverage exists in all six countries, and the rate of coverage ranges from $9 \%$ in Colombia to 39\% in Jamaica.

Mexican respondents were the most consistently positive about their health care and health care system, with top scores on five of the seven dependent variables (Table 1). For example, three-quarters were confident that if they were sick, they would receive effective treatment. The next closest country was Panama, with 57\% reporting confidence. At the other end of the spectrum, respondents from Brazil had the most consistently negative responses, with the lowest scores on four of the seven variables. Only 34\% of Brazilians reported confidence that they would receive effective treatment if sick.
Table 2 shows the bivariate relationships between respondents' education level and their assessment of the health care system for each country. Jamaica was the only country in which we observed a relationship between education level and belief that their health care system needed major reform. Jamaicans with primary education were twice as likely as those with a college degree to believe their system needed major reform (46\% vs. $23 \%$ ). Only in Brazil did those with the highest educational attainment have significantly more confidence they would receive effective treatment than those with lower education levels $(46 \%$ for college graduates compared to $32 \%$ and $33 \%$, respectively, for those who completed high school and primary school). In Jamaica there was a significant relationship, but it was high school graduates who had significantly lower confidence than persons with either a primary school education or a college degree.

In four of the six countries (Brazil, El Salvador, Jamaica, and Mexico), those with higher education were more likely to have a regular doctor than those with lower education (Table 2). This relationship was particularly strong in Brazil, where college-educated respondents were almost two and a half times as likely to have a regular doctor as were those with primary education. In Brazil, Jamaica, and Panama those with higher education levels were significantly less likely to report having skipped a doctor visit due to cost of care in the last year than were lower educated respondents. This relationship was largest in magnitude in Brazil and Jamaica, where those with a college degree reported 14 and 13 points, respectively, less likelihood of skipping a doctor visit than did those with primary education.

Brazil and Jamaica again stood out for having greater inequality in respondents' experience with their general practitioner (Table 2). In both countries there was significant inequality for two of the three variables. Seventy-nine percent of college-educated respondents in Jamaica reported being able to ask their general practitioner (GP) questions, compared to $56 \%$ of those with less than a high school degree; in Brazil the corresponding percentages were $71 \%$ and $58 \%$. In Mexico and Panama, highereducated respondents also reported better-quality general practitioners than 
TABLE 1. Characteristics of respondents in six Latin American and Caribbean countries to Inter-American Development Bank (IADB) Survey on Access, Experience, and Coordination of Primary Health Care in Latin America and the Caribbean, 2012-2014

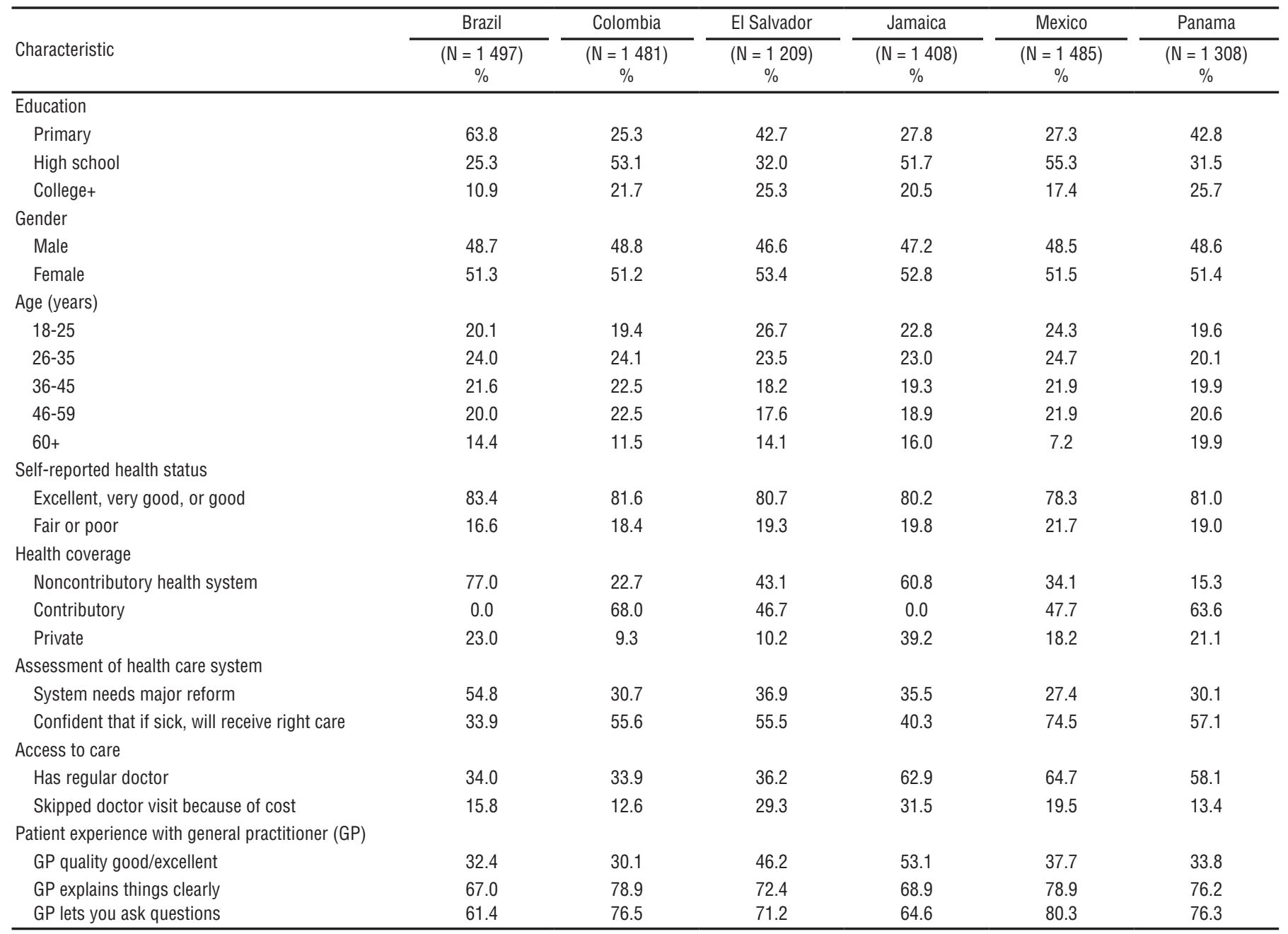

Source: Authors' analysis of the IADB survey. The survey response rates were: Brazil, 40.7\%; Colombia, 29.0\%; El Salvador, 43.8\%; Jamaica, 31.1\%; Mexico, 31.0\%; and Panama, $33.8 \%$.

TABLE 2. Bivariate relationships between survey respondents' education level and their assessment of health care system, access to care, and experience with their general practitioner, 2012-2014, in study of socioeconomic equity in health experiences in six Latin American and Caribbean countries ${ }^{a}$

\begin{tabular}{|c|c|c|c|c|c|c|}
\hline \multirow[b]{2}{*}{ Health care experience by education level } & Brazil & Colombia & El Salvador & Jamaica & Mexico & Panama \\
\hline & $\begin{array}{c}(\mathrm{N}=1497) \\
\%\end{array}$ & $\begin{array}{c}(\mathrm{N}=1481) \\
\%\end{array}$ & $\begin{array}{c}(\mathrm{N}=1209) \\
\%\end{array}$ & $\begin{array}{c}(N=1408) \\
\%\end{array}$ & $\begin{array}{c}(\mathrm{N}=1485) \\
\%\end{array}$ & $\begin{array}{c}(\mathrm{N}=1308) \\
\%\end{array}$ \\
\hline \multicolumn{7}{|l|}{ Assessment of health care system } \\
\hline Primary & 56.3 & 27.8 & 35.3 & 46.2 & 29.4 & 29.7 \\
\hline High school & 54.4 & 31.0 & 36.4 & 34.8 & 27.9 & 27.6 \\
\hline College+ & 46.5 & 33.8 & 35.5 & 23.0 & 22.2 & 26.4 \\
\hline \multicolumn{7}{|l|}{ Confident that if sick, will receive right care } \\
\hline Primary & 32.5 & 56.0 & 58.6 & 43.2 & 77.1 & 57.4 \\
\hline High school & 32.3 & 55.2 & 54.2 & 34.6 & 73.4 & 56.8 \\
\hline College+ & 46.3 & 57.1 & 56.5 & 49.5 & 71.5 & 56.8 \\
\hline$p$ value & .01 & .91 & .52 & $<.01$ & .48 & .98 \\
\hline
\end{tabular}


TABLE 2. (Continued)

\begin{tabular}{|c|c|c|c|c|c|c|}
\hline \multirow[b]{2}{*}{ Health care experience by education level } & Brazil & Colombia & El Salvador & Jamaica & Mexico & Panama \\
\hline & $\begin{array}{c}(\mathrm{N}=1497) \\
\%\end{array}$ & $\begin{array}{c}(\mathrm{N}=1481) \\
\%\end{array}$ & $\begin{array}{c}(\mathrm{N}=1209) \\
\%\end{array}$ & $\begin{array}{c}(\mathrm{N}=1408) \\
\%\end{array}$ & $\begin{array}{c}(\mathrm{N}=1485) \\
\%\end{array}$ & $\begin{array}{c}(\mathrm{N}=1308) \\
\%\end{array}$ \\
\hline \multicolumn{7}{|l|}{ Access to care } \\
\hline Primary & 27.8 & 44.0 & 36.3 & 56.9 & 58.2 & 57.5 \\
\hline High school & 34.9 & 29.8 & 30.6 & 60.4 & 65.9 & 57.4 \\
\hline College+ & 68.8 & 32.8 & 47.8 & 78.7 & 72.5 & 57.0 \\
\hline \multicolumn{7}{|l|}{ Skipped doctor visit because of cost } \\
\hline Primary & 18.8 & 15.6 & 31.6 & 35.1 & 22.8 & 17.5 \\
\hline High school & 13.1 & 12.6 & 28.7 & 33.5 & 19.0 & 8.8 \\
\hline College+ & 4.8 & 9.5 & 26.0 & 22.1 & 18.1 & 12.0 \\
\hline$p$ value & $<.01$ & .23 & .35 & $<.01$ & .52 & $<.01$ \\
\hline \multicolumn{7}{|l|}{ Experience with general practitioner (GP) } \\
\hline College+ & 53.5 & 34.9 & 46.3 & 58.8 & 59.5 & 43.4 \\
\hline$p$ value & $<.01$ & .43 & .02 & .16 & $<.01$ & $<.01$ \\
\hline \multicolumn{7}{|l|}{ GP explains things clearly } \\
\hline Primary & 63.9 & 77.9 & 72.1 & 62.2 & 73.0 & 71.6 \\
\hline High school & 73.1 & 80.7 & 64.9 & 67.1 & 79.5 & 80.5 \\
\hline College+ & 70.7 & 76.9 & 77.6 & 81.6 & 84.5 & 78.8 \\
\hline$p$ value & .08 & .65 & .06 & $<.01$ & .11 & .06 \\
\hline \multicolumn{7}{|l|}{ GP lets you ask questions } \\
\hline Primary & 58.0 & 70.7 & 73.0 & 55.6 & 76.1 & 73.9 \\
\hline High school & 65.5 & 78.7 & 68.8 & 63.8 & 81.0 & 80.5 \\
\hline College+ & 70.9 & 78.4 & 72.9 & 78.6 & 84.4 & 73.8 \\
\hline
\end{tabular}

Source: Authors' analysis of the Inter-American Development Bank (IADB) Survey on Access, Experience, and Coordination of Primary Health Care in Latin America and the Caribbean.

did those with less education, while in El Salvador the reverse pattern was observed.

In all six countries, education level was highly related to the respondents' type of health coverage (Table 3 ). Across all the countries, those with primary education were three times as likely to have noncontributory coverage as were those with college degrees, while college graduates were 2.8 times as likely to have private coverage and 1.6 times as likely to have contributory coverage as were those with primary education. In Brazil, respondents with college degrees were almost 7 times as likely as those with primary education to have private coverage.

Table 4 presents the multivariate regression results for Brazil and Jamaica, the two countries with the greatest education-based inequality in bivariate analyses. (Results for the four other countries are available upon request from the authors.) For Jamaican respondents, education level was still significantly related to four of the five outcomes that it was related to in bivariate analyses. Jamaican college graduates, for example, were more likely to report that their general practitioner explained things clearly (odds ratio $(\mathrm{OR})=2.37$ ) and let them ask questions $(\mathrm{OR}=2.53)$ as compared to those with only a primary education. Private coverage was also related to five of the seven more positive health experience outcomes, as compared to those with public (noncontributory) health coverage.

For Brazilian respondents, after controlling for type of health coverage and demographic characteristics, education level was only related to one of the five health experience variables it had been related to in bivariate analyses: skipping a doctor visit because of the cost. However, private insurance coverage was positively related to all seven dependent variables. Those with private coverage had .71 the odds of believing the health system needed major reform as those in the public system, and 12.14 times the odds of having a regular doctor as compared to those with noncontributory coverage.

In the other four countries, education was positively related to either no health outcomes (Colombia), one health outcome (El Salvador, Mexico), or two outcomes (Panama). On the other hand, the type of health coverage (generally private and contributory) was consistently related to better outcomes in Mexico than was noncontributory coverage (six of seven outcomes), and also in El Salvador (four of seven outcomes). In Colombia and Panama, respondents did not differ at all in their experiences based upon whether they had contributory or noncontributory coverage. Those with private coverage in the two countries were more likely to report having good- to excellent-quality general practitioners than were those with noncontributory coverage (ORs of 2.20 and 3.26, 
TABLE 3. Relationships between respondents' education level and type of health coverage, 2012-2014, in study of socioeconomic equity in health experiences in six Latin American and Caribbean countries

\begin{tabular}{|c|c|c|c|c|}
\hline \multirow[b]{2}{*}{ Country/Education level } & \multicolumn{3}{|c|}{ Type of health coverage } & \multirow[b]{2}{*}{$p$ value } \\
\hline & $\begin{array}{c}\text { Noncontributory } \\
(\%)\end{array}$ & $\begin{array}{c}\text { Contributory } \\
(\%)\end{array}$ & $\begin{array}{c}\text { Private } \\
(\%)\end{array}$ & \\
\hline \multicolumn{5}{|l|}{$\overline{\text { Brazil }}$} \\
\hline Primary & 89.3 & 0.0 & 10.7 & $<.01$ \\
\hline High school & 67.3 & 0.0 & 32.8 & \\
\hline College+ & 26.8 & 0.0 & 73.3 & \\
\hline \multicolumn{5}{|l|}{ Colombia } \\
\hline Primary & 28.4 & 64.9 & 6.8 & $<.01$ \\
\hline High school & 27.2 & 66.4 & 6.5 & \\
\hline College+ & 4.8 & 77.1 & 18.1 & \\
\hline \multicolumn{5}{|l|}{ El Salvador } \\
\hline Primary & 50.8 & 40.8 & 8.4 & $<.01$ \\
\hline High school & 41.6 & 47.6 & 10.8 & \\
\hline College+ & 28.9 & 59.3 & 11.8 & \\
\hline \multicolumn{5}{|l|}{ Jamaica } \\
\hline Primary & 76.5 & 0.0 & 23.5 & $<.01$ \\
\hline High school & 61.7 & 0.0 & 38.3 & \\
\hline College+ & 36.3 & 0.0 & 63.7 & \\
\hline \multicolumn{5}{|l|}{ Mexico } \\
\hline Primary & 54.6 & 34.6 & 10.8 & $<.01$ \\
\hline High school & 29.1 & 51.6 & 19.3 & \\
\hline College+ & 15.8 & 57.9 & 26.3 & \\
\hline \multicolumn{5}{|l|}{ Panama } \\
\hline Primary & 19.7 & 65.2 & 15.1 & $<.01$ \\
\hline High school & 21.1 & 58.6 & 20.3 & \\
\hline College+ & 5.0 & 64.3 & 30.8 & \\
\hline
\end{tabular}

Source: Authors' analysis of Inter-American Development Bank (IADB) Survey on Access, Experience, and Coordination of Primary Health Care in Latin America and the Caribbean.

respectively), but there were no other significant differences in coverage across the other six variables.

\section{DISCUSSION}

In our study we found a large range in education-based disparities in health care experience in six Latin American and Caribbean countries. On one end of the spectrum, in Colombia, there were no education-based disparities observed across seven health experience variables, despite the country having the greatest income inequality of the countries studied (28). In contrast, in Jamaica and Brazil, we observed that college-educated respondents had substantially better health care experiences for five of the seven variables in bivariate analyses, compared to those with primary education. In Jamaica, almost all of these relationships remained when we controlled for type of health coverage and demographic characteristics. In Brazil, in contrast, for all outcomes, we found those with private health coverage reported substantially better outcomes than did those with public coverage. This wiped out almost all the education-based inequality since higher educated people in Brazil were substantially more likely to enroll in private health coverage. This wide range in equity across countries in health outcomes is not unlike what the Commonwealth Fund has documented across highincome countries $(29,30)$.

There was also substantial variation in whether health care experiences differed based upon type of health coverage. In Brazil, those with private coverage reported better experience for all seven health outcomes than did those with noncontributory coverage (there is no contributory coverage in Brazil). In El Salvador, Jamaica, and Mexico, there was also substantial inequality by type of health coverage. This is not entirely surprising since private coverage in these countries is in addition to public coverage, so we would expect at least equal if not better outcomes. However, we observed very limited differences in health experiences by type of health coverage in Colombia and Panama.

Our findings challenge prior notions that segmented health care systems necessarily result in health care inequity $(2,16)$. Colombia, which has noncontributory, contributory, and private health coverage, showed no education-based inequality and minimal health coveragebased inequality in this study. On the other hand, Jamaica, which has a unified public system, exhibited the greatest education-based inequality. Brazil, also with a unified public system, exhibited the greatest health coverage-based inequality. These findings in no way suggest that greater segmentation results in more equity. In Colombia, the benefit packages in the two public systems were equalized, first in response to a court order, and subsequently by legislative reform, and funding across the two public systems is cross-subsidized $(6,31,32)$. Furthermore, problems with supply of medications are less frequent than what is observed in neighboring Brazil, where lack of availability in public facilities makes people purchase medications from private pharmacies (33).

This study's findings underscore the importance of monitoring both equity and overall health care performance. While quality and equity can track together (as they did in the case of Brazil, which had the lowest quality and was one of two countries with the greatest inequity), quality and equity measures within a country can differ substantially. In Mexico, for example, those with a college education were $25 \%$ more likely to report having a regular doctor as compared to those with a primary education. However, the rate of having a regular doctor for Mexicans with primary education, 58\%, was substantially higher than the rate for any educational group in Colombia, where more education was not associated with greater likelihood of having a regular doctor. This highlights that equity without high quality is not sufficient, and that health systems should strive to achieve both. We further recommend that the quality measures monitored should include patient-reported health experience measures, like those examined in this study, since they have the potential to focus quality improvement efforts on patient-centered outcomes (34). 


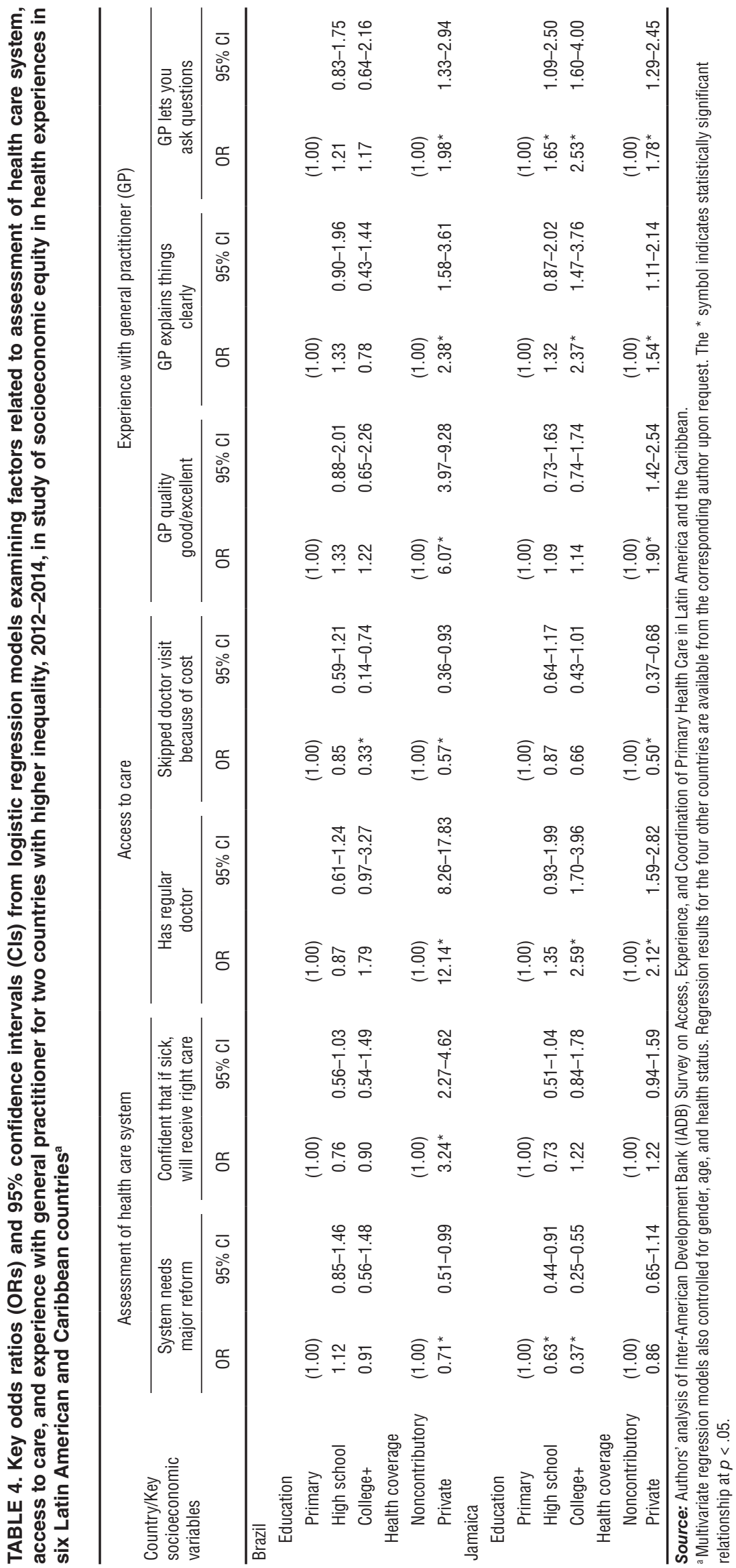


Our findings should be interpreted in light of the study's limitations. The key limitations are its cross-sectional design and relatively low response rates. Since the surveys were conducted by telephone, poorer and more rural populations are likely underrepresented. We did not have a measure of rural residence, so we are unable to state how consistently rural populations were underrepresented in the countries. The average level of education at a given attainment level may differ among the countries, which would also impact our findings. It should also be noted that our findings on Colombia's health system's equity differ from some, though not all, prior studies (35-37). However, the studies finding greater inequity in Colombia examined specific regions of the country or were conducted prior to the country's effort to provide more equitable health services $(35,36)$. The results of large inequalities in Brazil and Jamaica, however, are consistent with prior research finding substantial inequalities $(38,39)$.
Lastly, health care systems in LAC continue to evolve. Our findings describe the state of equity in health care experiences in 2012-2014, and ongoing monitoring is important as patterns may have changed more recently.

\section{Conclusions}

We observed substantial differences in education-based disparities in health care experiences in six LAC countries. Colombia was the exemplar despite being the country with the highest income inequality. We observed no education-based inequality in Colombia across the seven health experience variables, and only one instance in which those with private coverage reported an advantage over respondents with noncontributory coverage. In contrast, we observed substantial education-based and health coverage-based inequality in Brazil and Jamaica. In Brazil, the education-based inequality seems to be driven by higher educated people being more

\section{REFERENCES}

1. Cavangero E, Almeida G, Sloane Seely E, Marinho F. Setting the context for universal health coverage reforms in Latin America and the Caribbean. In: Dmytraczenko T, Almeida G, eds. Toward universal health coverage and equity in Latin America and the Caribbean: evidence from selected countries. Washington, D.C.: World Bank; 2015;19-51.

2. Frenk J. Leading the way towards universal health coverage: a call to action. Lancet. 2015 Apr 4;385(9975):1352-8.

3. Bossert T, Blanchet N, Sheetz S, Pinto D, Cali J, Perez Cuevas R. Comparative review of health system integration in selected countries in Latin America. Washington, D.C.: Inter-American Development Bank; 2014.

4. Pan American Health Organization. Sustainable Health Agenda For The Americas 2018-2030: a call to action for health and well-being in the Region. Washington, D.C.: PAHO; 2017.

5. Pérez-Cuevas R, Guanais FC, Doubova SV, Pinzón L, Tejerina L, Pinto Masis D, et al. Understanding public perception of the need for major change in Latin American healthcare systems. Health Policy Plan. 2017 Jul 1;32(6):816-24.

6. Dmytraczenko T, Montenegro Torres F, Aten A. Universal health coverage policies in Latin America and the Caribbean. In: Dmytraczenko T, Almeida G, eds. Toward universal health coverage and equity in Latin America and the Caribbean: evidence from selected countries. Washington, D.C.: World Bank; 2015;53-80.
7. Bárcena A. Health protection as a citizen's right. Lancet. 2015 Apr 4;385(9975):e29-30.

8. Dmytraczenko T, Almeida G. Conclusions. In: Dmytraczenko $T$, Almeida $G$, eds. Toward universal health coverage and equity in Latin America and the Caribbean. Washington, D.C.: The World Bank; 2015:185-93.

9. Economic Commission for Latin America and the Caribbean. Social panorama of Latin America. Santiago: ECLAC; 2014.

10. Evans D, Elovainio R, Humphreys G, Chisholm D, Kutzin J, Russell S, et al. World health report: health systems financing: the path to universal coverage. Geneva: World Health Organization: 2010. versal health coverage: final report of the WHO Consultative Group on Equity and Universal Health Coverage. Geneva: World Health Organization; 2014. O, Lezana M, Knaul F. Universal health coverage: friend or foe of health equity? Lancet. 2011 Jun 25;377(9784):2160-1.

13. Frenz P, Vega J. Universal health coverage with equity: what we know, don't know and need to know. Available from: http: / / brasil.campusvirtualsp.org/sites / default/files/9coverage_with_equity.pdf Accessed 16 July 2018.

14. O'Connell T, Rasanathan K, Chopra M. What does universal health coverage mean? Lancet. 2014 Jan;383(9913):277-9.

15. United Nations Development Programme. Humanity divided: confronting inequality
11. Ottersen T, Norheim O, Group WC. Making fair choices on the path to uni-

12. Gwatkin DR, Ergo A, Gómez-Dantés likely to have private health coverage, whereas in Jamaica we observed both education and health coverage disparities in multivariate models. Future research should seek to understand the policies and strategies that have resulted in Colombia achieving comparative equity, and Jamaica and Brazil demonstrating comparative inequality, so that countries can learn from these positive and negative exemplars.

Conflicts of interest. Professor Greene has no conflicts of interest to report. Dr. Guanais is an employee of the Inter-American Development Bank (IDB). The opinions expressed in the article are the authors' own and do not necessarily reflect the views of the IDB, its board of directors, or its technical advisers.

Disclaimer. Authors hold sole responsibility for the views expressed in the manuscript, which may not necessarily reflect the opinion or policy of the RPSP/ PAJPH or PAHO. in developing countries. Available from: http:/ / www.undp.org/content/ $\mathrm{dam} /$ undp/library/PovertyReduction/ Inclusivedevelopment / Humanity Divided/HumanityDivided_Full-Report. pdf Accessed16 July 2018.

16. Cotlear D, Gómez-Dantés O, Knaul F, Atun $\mathrm{R}$, Barreto ICHC, Cetrángolo O, et al. Overcoming social segregation in health care in Latin America. Lancet. 2015 Mar;385(9974):1248-59.

17. Atun R, de Andrade LOM, Almeida G, Cotlear D, Dmytraczenko T, Frenz P, et al. Health-system reform and universal health coverage in Latin America. Lancet. 2015 Mar;385(9974):1230-47.

18. Knaul FM, Frenk J. Health insurance in Mexico: achieving universal coverage through structural reform. Health Aff (Millwood). 2005 Nov 1;24(6):1467-76.

19. Londoño J-L, Frenk J. Structured pluralism: towards an innovative model for health system reform in Latin America. Health Policy (New York). 1997 Jul;41(1): $1-36$.

20. Heredia N, Laurell AC, Feo O, Noronha J, González-Guzmán R, Torres-Tovar M. The right to health: what model for Latin America? Lancet. 2015 Apr 4;385(9975):e34-7.

21. Dmytraczenko T, Almeida G, Werneck H, Cercone J, Diaz Y, Maceria D, et al. Progress toward universal health coverage in Latin America and the Caribbean: outcomes, utilization, and financial protections. In: Dmytraczenko $\mathrm{T}$, Almeida G, eds. Toward universal health 
coverage and equity in Latin America and the Caribbean. Washington, D.C.: The World Bank; 2015:81-146.

22. Almeida G, Sarti FM, Ferreira FF, Diaz MDM, Campino ACC. Analysis of the evolution and determinants of income-related inequalities in the Brazilian health system, 1998-2008. Rev Panam Salud Publica. 2013;33(2):90-7.

23. Barraza-Lloréns M, Panopoulou G, Díaz BY. Income-related inequalities and inequities in health and health care utilization in Mexico, 2000-2006. Rev Panam Salud Publica. 2013;33(2):122-30.

24. Macinko J, Guanais FC, Mullachery P, Jimenez G. Gaps in primary care and health system performance in six Latin American and Caribbean countries. Health Aff (Millwood). 2016 Aug 1;35(8):1513-21.

25. Kim MK, Blendon RJ, Benson JM. What is driving people's dissatisfaction with their own health care in 17 Latin American countries? Health Expect. 2013 Jun 1;16(2):155-63.

26. Schoen C, Osborn R, Squires D, Doty MM. Access, affordability, and insurance complexity are often worse in the United States compared to ten other countries. Health Aff (Millwood). 2013 Dec 1;32(12):2205-15.

27. Schoen C, Osborn R, Doty MM, Bishop M, Peugh J, Murukutla N. Toward higher-performance health systems: adults' health care experiences in seven countries, 2007. Health Aff. 2007;26:W717-34.

28. World Bank. GINI Index (World Bank Estimate). Available from: https:// data.worldbank.org/indicator/SI.POV. GINI?end=2014\&start=2001 Accessed 16 July 2018.
29. Osborn R, Squires D, Doty MM, Sarnak DO, Schneider EC. In new survey of eleven countries, US adults still struggle with access to and affordability of health care. Health Aff (Millwood). 2016 Dec 1;35(12): 2327-36.

30. Schoen C, Doty MM. Inequities in access to medical care in five countries: findings from the 2001 Commonwealth Fund International Health Policy Survey. Health Policy. 2004 Mar 1;67(3):309-22.

31. Organisation for Economic Co-operation and Development. OECD reviews of health systems: Colombia 2016. Available from: http://www.keepeek. com/Digital-Asset-Management/oecd/ social-issues-migration-health / oecdreviews-of-health-systems-colombia2015_9789264248908-en\#page4 Accessed 16 July 2018

32. Yamin AE, Parra-Vera O. How do courts set health policy? The case of the Colombian Constitutional Court. PLoS Med. 2009 Feb 17;6(2):e1000032.

33. Garcia-Subirats I, Vargas I, MogollonPerez A, De Paepe P, Ferreira da Silva $\mathrm{M}$, Unger $\mathrm{J}$, et al. Barriers in access to healthcare in countries with different health systems. A cross-sectional study in municipalities of central Colombia and north-eastern Brazil. Soc Sci Med. 2014 Apr 1;106:204-13.

34. Browne K, Roseman D, Shaller D, EdgmanLevitan S. Analysis \& commentary. Measuring patient experience as a strategy for improving primary care. Health Aff (Millwood). 2010 May;29(5):921-5.

35. Ruiz Gómez F, Zapata Jaramillo $T$, Garavito Beltrán L. Colombian health care system: results on equity for five health dimensions, 2003-2008. Rev Panam Salud Publica 2013 Feb;33(2):107-15.

36. Garcia-Subirats I, Vargas I, MogollónPérez A, De Paepe P, da Silva M, Unger $\mathrm{J}$, et al. Inequities in access to health care in different health systems: a study in municipalities of central Colombia and north-eastern Brazil. Int J Equity Health. 2014 Jan 31;13(1):10.

37. Restrepo-Méndez MC, Barros AJD Requejo J, Durán P, Serpa LA de F, França GVA, et al. Progress in reducing inequalities in reproductive, maternal, newborn, and child health in Latin America and the Caribbean: an unfinished agenda, Rev Panam Salud Publica. 2015 Jul; 38(1): 9-16.

38. Boccolini CS, de Souza Junior PRB. Inequities in healthcare utilization: results of the Brazilian National Health Survey, 2013. Int J Equity Health. 2016 Dec 17;15(1):150.

39. Ferguson TS, Younger-Coleman NOM, Tulloch-Reid MK, Hambleton IR, Francis DK, Bennett NR, et al. Educational health disparities in cardiovascular disease risk factors: findings from Jamaica Health and Lifestyle Survey 2007-2008. Front Cardiovasc Med. 2017 May 15;4:28.

Manuscript received on 16 November 2017. Revised version accepted for publication on 8 June 2018. 
RESUMEN

\section{Examen de la equidad socio- económica en cuanto a las experiencias de salud en seis países de América Latina y el Caribe}

Objetivo. La mayor parte de los países de América Latina y el Caribe está trabajando para lograr la cobertura universal de salud, por lo que asegurar la equidad es una prioridad para esas naciones. La meta de este estudio fue examinar en qué medida la situación socioeconómica de los adultos se relacionaba con la experiencia de atención de salud en seis países de América Latina y el Caribe.

Métodos. En este estudio transversal se examinó la relación entre el nivel educativo alcanzado y siete resultados en cuanto a la experiencia de salud en tres áreas: la evaluación del sistema de salud, el acceso a la atención y la experiencia con un médico general. En este trabajo, se usaron datos de una encuesta del Banco Interamericano de Desarrollo a adultos en Brasil, Colombia, El Salvador, Jamaica, México y Panamá, que se realizó entre el 2012 y el 2014.

Resultados. Brasil y Jamaica, dos países con cobertura pública unificada, se destacaron por tener una desigualdad notablemente mayor, según los resultados de los análisis bivariantes, en los que los entrevistados con mayor instrucción informaron mejores experiencias de atención de salud para cinco de los siete resultados. En el caso de Jamaica, las diferencias educativas permanecieron en gran medida después de los análisis multivariantes: los graduados universitarios (razón de posibilidades [OR] = 0,37 ) eran menos propensos, en comparación con quienes tenían educación primaria, a manifestar la reforma importante que necesita su sistema de salud y eran más propensos $(\mathrm{O}=2,57)$ a tener a un médico de cabecera. En Brasil, si bien las diferencias educativas se eliminaron en gran parte en los modelos con múltiples variables, las personas con cobertura privada manifestaron constantemente mejores resultados que aquellos con cobertura pública. En cambio, Colombia presentó la menor desigualdad a pesar de tener la desigualdad de ingresos más alta de los seis países.

Conclusiones. Se precisan investigaciones futuras para comprender las políticas y las estrategias que han llevado a que Colombia alcance niveles altos de equidad en la experiencia de atención de salud de pacientes, y a que Jamaica y Brasil presenten niveles altos de desigualdad.

Palabras clave Equidad en salud; equidad en cobertura; equidad en el acceso a los servicios de salud; América Latina; Indias Occidentales. 
RESUMO

Uma análise da equidade
socioeconômica em
experiências em saúde em
seis países da América
Latina e do Caribe

Objetivo. Na América Latina e no Caribe, os países estão trabalhando para alcançar a cobertura universal de saúde e uma das prioridades é assegurar a equidade nestas nações. O objetivo deste estudo foi examinar a relação entre a situação socioeconômica e a experiência em atenção de saúde de adultos em seis países da ALC.

Métodos. Foi realizado um estudo transversal para examinar a relação entre aproveitamento escolar e sete desfechos da experiência em saúde em três áreas distintas: avaliação do sistema de saúde, acesso à assistência e experiência com o clínico geral. Foram usados dados de uma pesquisa do Banco Interamericano de Desenvolvimento realizada com adultos no Brasil, Colômbia, El Salvador, Jamaica, México e Panamá em 2012-2014.

Resultados. O Brasil e a Jamaica, os dois países com um sistema único de cobertura da rede pública de saúde, se destacaram por ter consideravelmente maior desigualdade segundo os resultados das análises bivariadas, sendo que os participantes com maior nível de instrução informaram experiências melhores em atenção de saúde em cinco dos sete desfechos. Na Jamaica, as diferenças relativas ao nível educacional permaneceram em grande parte nas análises multivariadas: em comparação aos indivíduos com nível primário de educação, os adultos com nível universitário (odds ratio [OR] 0,37) apontaram com menor frequência a necessidade de uma ampla reforma no sistema de saúde e indicaram com maior frequência $(\mathrm{OR} 2,57)$ ter um médico habitual. No Brasil, as diferenças relativas ao nível educacional foram na sua maior parte eliminadas nos modelos multivariados, apesar de os indivíduos com plano de saúde privado terem consistentemente informado melhores desfechos que os indivíduos atendidos na rede pública. Em contraste, o menor grau de desigualdade foi observado na Colômbia apesar de o país ter a maior desigualdade de renda dos seis países estudados.

Conclusões. Osutras pesquisas são necessárias para compreender as políticas e as estratégias responsáveis pelo alto grau de equidade na experiência em atenção de saúde dos pacientes na Colômbia e pelos altos níveis de desigualdade na Jamaica e no Brasil.

Palavras-chave
Equidade em saúde; equidade em cobertura; equidade no acesso aos serviços de saúde; América Latina; Indias Ocidentais. 